\title{
Candesartan cilexetil/hydrochlorothiazide
}

\section{combination treatment versus high-dose candesartan cilexetil monotherapy in patients with mild to moderate cardiovascular risk (CHILI Triple T)}

This article was published in the following Dove Press journal:

Vascular Health and Risk Management

I6 February 201 I

Number of times this article has been viewed

\author{
Gerd Bönner' \\ Bernhard Landers ${ }^{2}$ \\ Peter Bramlage 3 \\ 'Park-Klinikum Bad Krozingen, \\ Germany; ${ }^{2}$ Internal Medicine Practice, \\ Diabetes Center, Mayen, Germany; \\ ${ }^{3}$ Institute for Cardiovascular \\ Pharmacology and Epidemiology, \\ Mahlow, Germany
}

Background: Candesartan cilexetil has been shown to effectively reduce blood pressure and cardiovascular risk. Whether it is advantageous to combine candesartan cilexetil with low-dose hydrochlorothiazide (HCTZ) or uptitrate it in cases of insufficient blood pressure control has not been fully investigated under routine clinical conditions.

Methods: CHILI Triple T is a prospective, noninterventional, observational study. Patients with uncontrolled hypertension and added cardiovascular risk received a fixed-dose combination of candesartan cilexetil $16 \mathrm{mg}$ and HCTZ $12.5 \mathrm{mg}$ (combination therapy group) or high-dose monotherapy with candesartan cilexetil $32 \mathrm{mg}$ (high-dose monotherapy group).

Results: A total of 4600 patients with a mean age of $63.1 \pm 11.0$ years, of which $44.7 \%$ were female, was included. The combination therapy group had 3337 patients, and the high-dose monotherapy group 1263 patients. Patients in both treatment groups were comparable with respect to age and gender, but patients receiving high-dose monotherapy had a slightly higher mean systolic blood pressure, more prior revascularizations, renal insufficiency, diabetic nephropathy, peripheral artery disease, and a lower ankle brachial index. The use of combination therapy resulted in a blood pressure reduction of $-28.5 \pm 13.8 /-14.2 \pm 9.4 \mathrm{~mm} \mathrm{Hg}(P<0.001$ vs $160.2 \pm 13.3 / 94.5 \pm 8.2 \mathrm{~mm} \mathrm{Hg}$ at baseline). The use of high-dose monotherapy reduced blood pressure by $-29.73 \pm 15.3 /-14.1 \pm 9.6 \mathrm{~mm} \mathrm{Hg}(P<0.001$ vs $162.4 \pm 14.7 / 94.7 \pm 8.7 \mathrm{~mm}$ $\mathrm{Hg}$ at baseline). Differences in subgroups of patients defined by age, gender, body mass index, dyslipidemia, waist circumference, smoking, prior cardiovascular event, glomerular filtration rate, and microalbuminuria were minor, although partially significant. Tolerability was excellent, with only 28 out of 3358 patients $(0.8 \%)$ in the combination therapy group and 15 out of 1273 patients $(1.2 \%)$ in the high-dose monotherapy group experiencing any adverse event, of which one in each group was considered to be serious $(<0.1 \%)$.

Conclusions: Both the fixed-dose combination of candesartan cilexetil $16 \mathrm{mg}$ and HCTZ $12.5 \mathrm{mg}$ and high-dose monotherapy with candesartan $32 \mathrm{mg}$ were highly effective in lowering blood pressure in patients at increased cardiovascular risk. Tolerability was excellent. The choice of either strategy therefore largely depends on the principal aim: blood pressure reduction with pronounced volume restriction or pronounced additional end-organ protection.

Keywords: essential hypertension, combination therapy, high-dose monotherapy, candesartan cilexetil, noninterventional study, diuretics, Phase IV 


\section{Background}

Angiotensin receptor blockers (ARBs) are highly effective at reducing blood pressure in patients with arterial hypertension and have shown to protect against end-organ damage. Candesartan cilexetil is an ARB that has been shown to provide effective blood pressure reduction alone ${ }^{1-4}$ or in combination with hydrochlorothiazide (HCTZ). ${ }^{5-7}$ Its particular benefit, however, is related not only to its blood pressure-lowering effect but more to its protective effect on end-organs such as the heart, ${ }^{8-11}$ kidneys, ${ }^{12-16}$ and brain. ${ }^{17,18}$ This has usually been achieved in doses up to $32 \mathrm{mg}$ of candesartan cilexetil and is thought to be mediated by effects beyond blood pressure control. ${ }^{19}$

ARBs, including candesartan cilexetil, are frequently used as first-line monotherapy because of their high efficacy, tolerability, and patient compliance. ARB treatment is also an option in patients previously receiving antihypertensive monotherapy with angiotensin-converting enzyme (ACE) inhibitors, $\beta$-blockers, or calcium channel blockers, because patients can be safely switched, which results in additional blood pressure lowering. ${ }^{20}$ When blood pressure control at low ARB doses is not sufficient, either ARB doses may be increased or combination therapy initiated early. ${ }^{21}$ There is, however, no recommendation on the decision to either combine or increase dose, and reports on clinical experience from primary care are sparse.

We therefore designed a noninterventional study in primary care practice asking physicians to document patients at increased cardiovascular risk who had either been prescribed a fixed-dose combination of candesartan cilexetil $16 \mathrm{mg} / \mathrm{HCTZ} 12.5 \mathrm{mg}$ or a high-dose monotherapy with candesartan $32 \mathrm{mg}$ because blood pressure control under previous antihypertensive pharmacotherapy was insufficient. We chose a noninterventional design to cover the broadest possible patient spectrum and because results of these studies are directly applicable to clinical practice because of the high external validity of this study type.

\section{Patients and methods}

CHILI Triple $\mathrm{T}$ was a noninterventional, noncontrolled, open-label study with a 12 -week follow-up that was conducted with primary care physicians, internists, or diabetologists throughout Germany. The study was registered at the Bundesinstitut für Arzneimittel und Medizinprodukte (BfArM) and Kassenärztliche Bundesvereinigung (KBV) in accordance with paragraph 67, section 6 of the German Drug Act 2010. Applicable data protection regulations were respected. Participating physicians received remuneration for the documentation of patients in accordance with the Gebührenordnung für Ärzte (GOÄ). Ethical approval was obtained prior to commencement of the study by the Landesärztekammer Thüringen, Jena, Germany, on August 12, 2008. Written informed consent was obtained from all patients.

\section{Patients}

Patients aged at least 18 years were eligible for inclusion when a treatment decision to start candesartan $16 \mathrm{mg}$ and HCTZ $12.5 \mathrm{mg}$ or candesartan $32 \mathrm{mg}$ due to arterial hypertension had been made. Further necessary inclusion criteria were uncontrolled blood pressure ( $\geq 130 / 80 \mathrm{~mm} \mathrm{Hg}$ ) on prior antihypertensive therapy for at least 8 weeks, the presence of additional cardiovascular risk factors (eg, diabetes or hyperlipidemia), and compliance with the prescribing information of Blopress ${ }^{\circledR} 16 \mathrm{mg}$ Plus or Blopress $^{\circledR} 32 \mathrm{mg}$ (both Takeda Pharma GmbH, Aachen, Germany). Physicians were allowed to adjust the dose of any concomitant medication as necessary.

\section{Objective}

The objective of this study was to compare the efficacy and safety of a fixed-dose combination treatment strategy (candesartan cilexetil $16 \mathrm{mg}$ and HCTZ $12.5 \mathrm{mg}$ ) with high-dose monotherapy (candesartan cilexetil $32 \mathrm{mg}$ ). Treatment strategies were to be compared with respect to blood pressure target achievement and blood pressure achievement in patients with different cardiovascular risks at baseline, and to collect data on tolerability and drug safety in the respective treatment group.

\section{Variables}

Three visits were scheduled throughout a 12-week follow-up. At the first visit (enrolment), demographic data, body mass index (BMI), cardiovascular risk factors, concomitant disease conditions, previous or concomitant therapies, and a number of laboratory values were documented. At the mandatory second visit, blood pressure readings, blood glucose, antihypertensive pharmacotherapy, and adverse events were documented. At the end of the observation, blood pressure, antihypertensive treatment, and changes in laboratory values were documented. Blood pressure measurements were conducted in agreement with current guidelines after 5 minutes of rest. Treatment satisfaction was monitored as the proportion of physicians indicating patients reaching blood pressure goal and patients' compliance with treatment.

\section{Statistics}

The case report forms were collected by the clinical research organization Immedis GmbH, Königswinter, Germany. Case 
report forms were checked for consistency and a subset of case report forms verified with the source data $(8 \%)$. Regarding safety, the trial was adequately sized $(n=4600)$ to identify rare adverse events, ie, those that may not have been detected in previous clinical studies (incidence 1:1000) with a probability of $>95 \%$. The statistical analysis was performed descriptively and was interpreted in an explorative way. Comparisons were made for a number of variables and analyzed using descriptive statistics. The number of patients is given for each value, and differences were calculated in patients with values at baseline and follow-up (per protocol). Data were analyzed with SPSS for Windows, Version 17.02 (SPSS, Inc., Chicago, IL, USA). The tests applied are indicated in the legends of the tables and figures in this article.

\section{Results}

Between October 2008 and February 2009 a total of 4600 patients was included (safety population), of which 4527 were analyzed for efficacy. Patients were stratified into two groups according to treatment chosen: 3337 patients received candesartan cilexetil $16 \mathrm{mg}$ in a fixed-dose combination with $12.5 \mathrm{mg} \mathrm{HCTZ} \mathrm{(combination} \mathrm{therapy} \mathrm{group),} \mathrm{and} 1263$ patients received candesartan cilexetil $32 \mathrm{mg}$ (monotherapy group).

\section{Patient and clinical characteristics at baseline}

Patients had an overall mean age of $63.1 \pm 11.0$ years, $44.7 \%$ were female, and the mean blood pressure at baseline was $160.8 \pm 13.7 / 94.6 \pm 8.3 \mathrm{~mm} \mathrm{Hg}$ (office measurements). Although age and gender were comparable between groups, there was a statistically significant difference with respect to a slightly higher systolic blood pressure at baseline, more prior revascularization procedures, renal insufficiency, diabetic nephropathy, peripheral arterial disease, ankle brachial index $<0.9$, and pulse wave velocity $>12 \mathrm{~m} / \mathrm{s}$ in patients receiving candesartan cilexetil $32 \mathrm{mg}$ (Table 1).

Pharmacotherapy at baseline and during follow-up is illustrated in Table 2. $\beta$-blockers, ACE inhibitors, and calcium channel blockers were the most frequently used

Table I Baseline characteristics of the study population (UI)

\begin{tabular}{|c|c|c|c|c|c|}
\hline \multirow[t]{2}{*}{ Variables } & \multicolumn{2}{|c|}{$\begin{array}{l}\text { Candesartan } 16 \mathrm{mg}+ \\
\text { hydrochlorothiazide } 12.5 \mathrm{mg}\end{array}$} & \multicolumn{2}{|c|}{ Candesartan 32 mg } & \multirow{2}{*}{$\begin{array}{l}P \text {-value } \\
\text { combination vs } \\
\text { monotherapy }\end{array}$} \\
\hline & $\begin{array}{l}\text { No. of available } \\
\text { patient data }\end{array}$ & $\begin{array}{l}\% / \text { mean } \\
\pm \text { SD }\end{array}$ & $\begin{array}{l}\text { No. of available } \\
\text { patient data }\end{array}$ & $\begin{array}{l}\% / \text { mean } \\
\pm \text { SD }\end{array}$ & \\
\hline Males (\%) & 1828 & 54.8 & 713 & 56.5 & 0.288 \\
\hline Age (years) & 3328 & $63.3 \pm 11.1$ & 1259 & $62.8 \pm 10.6$ & 0.156 \\
\hline Waist circumference $(\mathrm{cm})$ & 2706 & $102.5 \pm 14.0$ & 1002 & $103.0 \pm 15.3$ & 0.388 \\
\hline Smokers (\%) & 729 & 21.8 & 276 & 21.9 & 0.953 \\
\hline \multicolumn{5}{|l|}{ Blood pressure office } & \\
\hline Systolic (mm Hg) & 3336 & $160 \pm 13$ & 1260 & $162 \pm 15$ & $<0.00$ I \\
\hline Diastolic (mm Hg) & 3337 & $94 \pm 8$ & 1259 & $95 \pm 9$ & 0.374 \\
\hline Diabetes (\%) & 240 & 7.2 & 92 & 7.3 & 0.792 \\
\hline \multicolumn{6}{|l|}{ Concomitant disease (\%) } \\
\hline Coronary artery disease & 1296 & 38.8 & 505 & 40.0 & 0.387 \\
\hline Myocardial infarction & 399 & 12.0 & 176 & 13.9 & 0.065 \\
\hline Angina pectoris & 753 & 22.6 & 309 & 24.5 & 0.151 \\
\hline Prior revascularization & 450 & 13.5 & 203 & I6. I & 0.018 \\
\hline Heart failure & 700 & 21.0 & 278 & 22.0 & 0.415 \\
\hline Stroke & 167 & 5.0 & 63 & 5.0 & 0.985 \\
\hline Renal insufficiency & 268 & 8.0 & 152 & 12.0 & $<0.001$ \\
\hline Diabetic nephropathy & 259 & 7.8 & 136 & 10.8 & 0.001 \\
\hline Diabetic retinopathy & 235 & 7.0 & 98 & 7.8 & 0.402 \\
\hline Peripheral artery disease & 406 & 12.2 & 187 & 14.8 & 0.018 \\
\hline $\begin{array}{l}\text { Prior cardiovascular disease } \\
\text { in first-grade relatives }\end{array}$ & 1944 & 58.3 & 731 & 57.9 & 0.868 \\
\hline $\mathrm{IMT}>0.9 \mathrm{~mm}$ or plaque & 505 & 70.5 & 235 & 69.7 & 0.083 \\
\hline $\mathrm{ABI}<0.9$ & 212 & 29.6 & 131 & 38.9 & $<0.001$ \\
\hline $\mathrm{PWV}>12 \mathrm{~ms}$ & 65 & 9.1 & 55 & 16.3 & $<0.001$ \\
\hline
\end{tabular}

Abbreviations: $A B I$, ankle brachial index; IMT, intima media thickness; PWV, pulse wave velocity; SD, standard deviation. 
Table 2 Pharmacotherapy for the treatment of hypertension at baseline (\% of patients)

\begin{tabular}{|c|c|c|c|c|c|}
\hline & \multicolumn{2}{|c|}{$\begin{array}{l}\text { Candesartan } 16 \mathrm{mg}+ \\
\text { hydrochlorothiazide } 12.5 \mathrm{mg}\end{array}$} & \multicolumn{2}{|c|}{ Candesartan 32 mg } & \multirow{2}{*}{$\begin{array}{l}P \text {-value } \\
\text { combination vs } \\
\text { monotherapy }\end{array}$} \\
\hline & No. of patients & $\%$ & No. of patients & $\%$ & \\
\hline \multicolumn{6}{|l|}{ Baseline } \\
\hline Any (of the 5 groups below) & 5264 & 95.8 & 2206 & 95.0 & 0.113 \\
\hline $\begin{array}{l}\text { Angiotensin-converting } \\
\text { enzyme inhibitors }\end{array}$ & 1613 & 29.4 & 642 & 27.7 & 0.128 \\
\hline Angiotensin receptor blockers & 425 & 7.7 & 217 & 9.3 & 0.018 \\
\hline$\beta$-blockers & $|56|$ & 28.4 & 636 & 27.4 & 0.359 \\
\hline Calcium channel blockers & 1049 & 19.1 & 424 & 18.3 & 0.390 \\
\hline Diuretics & 616 & 11.2 & 287 & 12.4 & 0.147 \\
\hline Candesartan 16 mg/hydrochlorothiazide $12.5 \mathrm{mg}$ & 5492 & 100.0 & n.a. & n.a. & n.a. \\
\hline Candesartan $32 \mathrm{mg}$ & n.a. & n.a. & 2321 & 100.0 & n.a. \\
\hline \multicolumn{6}{|l|}{ Concomitant pharmacotherapy } \\
\hline Any (of the 5 groups below) & 659 & 13.4 & 435 & 20.3 & $<0.001$ \\
\hline Angiotensin-converting enzyme inhibitors & 35 & 0.7 & 35 & 1.6 & 0.001 \\
\hline Angiotensin receptor blockers* & 46 & 0.9 & 18 & 0.8 & 0.706 \\
\hline$\beta$-blockers & 235 & 4.8 & 102 & 4.8 & 0.996 \\
\hline Calcium channel blockers & 210 & 4.3 & 105 & 4.9 & 0.228 \\
\hline Diuretics* & 133 & 2.7 & 175 & 8.2 & $<0.001$ \\
\hline
\end{tabular}

Note: *Other than candesartan $32 \mathrm{mg}$ or candesartan $16 \mathrm{mg}$ and hydrochlorothiazide $12.5 \mathrm{mg}$.

drugs at baseline. Either candesartan cilexetil in mono- or combination therapy was added to an existing regimen or prior medication was substituted, resulting in $100 \%$ coverage at baseline. Concomitant drug use was low and comparable except for a nominally more frequent use of diuretics in the monotherapy group $(8.2 \%$ vs $2.7 \%$; $P<0.001)$.

\section{Blood pressure reduction}

At baseline, patients had comparable blood pressure values in both treatment arms and in subgroups, defined by the presence of hypertension grade 1-3 (Figure 1). The use of combination therapy resulted in a blood pressure reduction of $-28.5 \pm 13.8 /-14.2 \pm 9.4 \mathrm{~mm} \mathrm{Hg}(P<0.001$ with blood pressure of $160.2 \pm 13.3 / 94.5 \pm 8.2 \mathrm{~mm} \mathrm{Hg}$ at baseline).

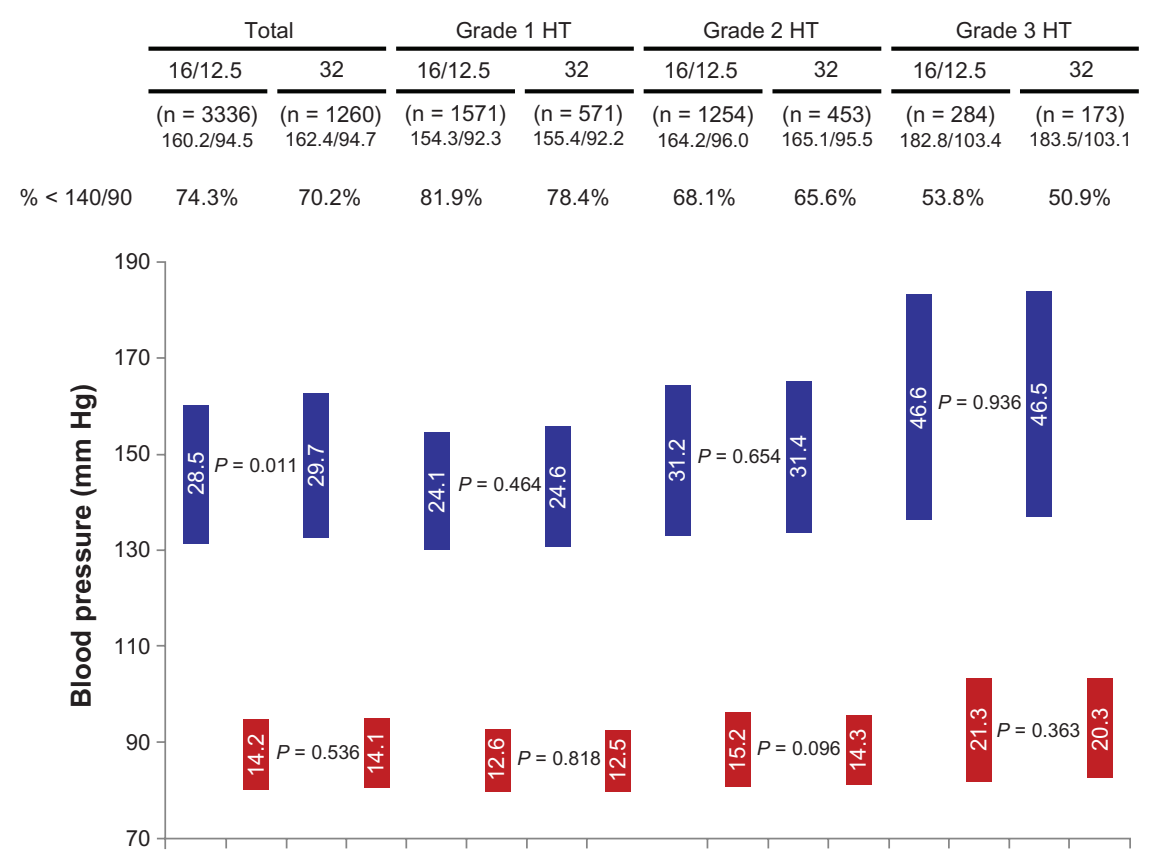

Figure I Blood pressure reduction overall and subgroups with grade I-3 hypertension (HT) I2 weeks after either candesartan cilexetil/hydrochlorothiazide combination (treatment arm I) or high-dose candesartan monotherapy $32 \mathrm{mg}$ (treatment arm 2). Blood pressure lowering in the total and the subgroups defined by the presence of grade I, 2, or 3 hypertension was significant $(P<0.00$ I, pairwise comparison). 
The use of high-dose monotherapy reduced blood pressure by $-29.73 \pm 15.3 /-14.1 \pm 9.6 \mathrm{~mm} \mathrm{Hg}(P<0.001$ with blood pressure of $162.4 \pm 14.7 / 94.7 \pm 8.7 \mathrm{~mm} \mathrm{Hg}$ at baseline) Differences were highly significant compared with baseline $(P<0.0001)$ and significant for the difference between systolic blood pressure values $(P=0.011)$. Target blood pressure achievement $(<140 / 90 \mathrm{~mm} \mathrm{Hg}$ ) was $74.3 \%$ in the combination therapy group and $70.2 \%$ in the monotherapy group.

The treatment-induced blood pressure reduction for patient groups, defined by the presence of hypertension grade 1-3 (see mean blood pressure readings at baseline in the respective subgroups), is illustrated in Figure 1. Blood pressure reduction was moderate in grade 1 hypertension
(-24.1/-12.6 mm Hg combination vs $-24.6 /-12.5 \mathrm{~mm} \mathrm{Hg}$ monotherapy; both $P<0.0001$ vs baseline), increased in grade 2 hypertension ( $-31.2 /-15.2$ vs $-31.4 /-14.3$; both $P<0.0001$ vs baseline), and was strongest in patients with grade 3 hypertension $(-46.6 /-21.3$ vs -46.5 vs -20.3 ; both $P<0.0001$ vs baseline). The correlation (Pearson 0.754 ) between blood pressure at baseline and blood pressure reduction was highly significant $(P<0.001)$; differences between mono- and combination therapy were not observed $(P=$ n.s. $)$.

Both patient groups had mostly either high or very high added risk at baseline, defined by blood pressure readings and the presence of comorbid risk factors and disease as
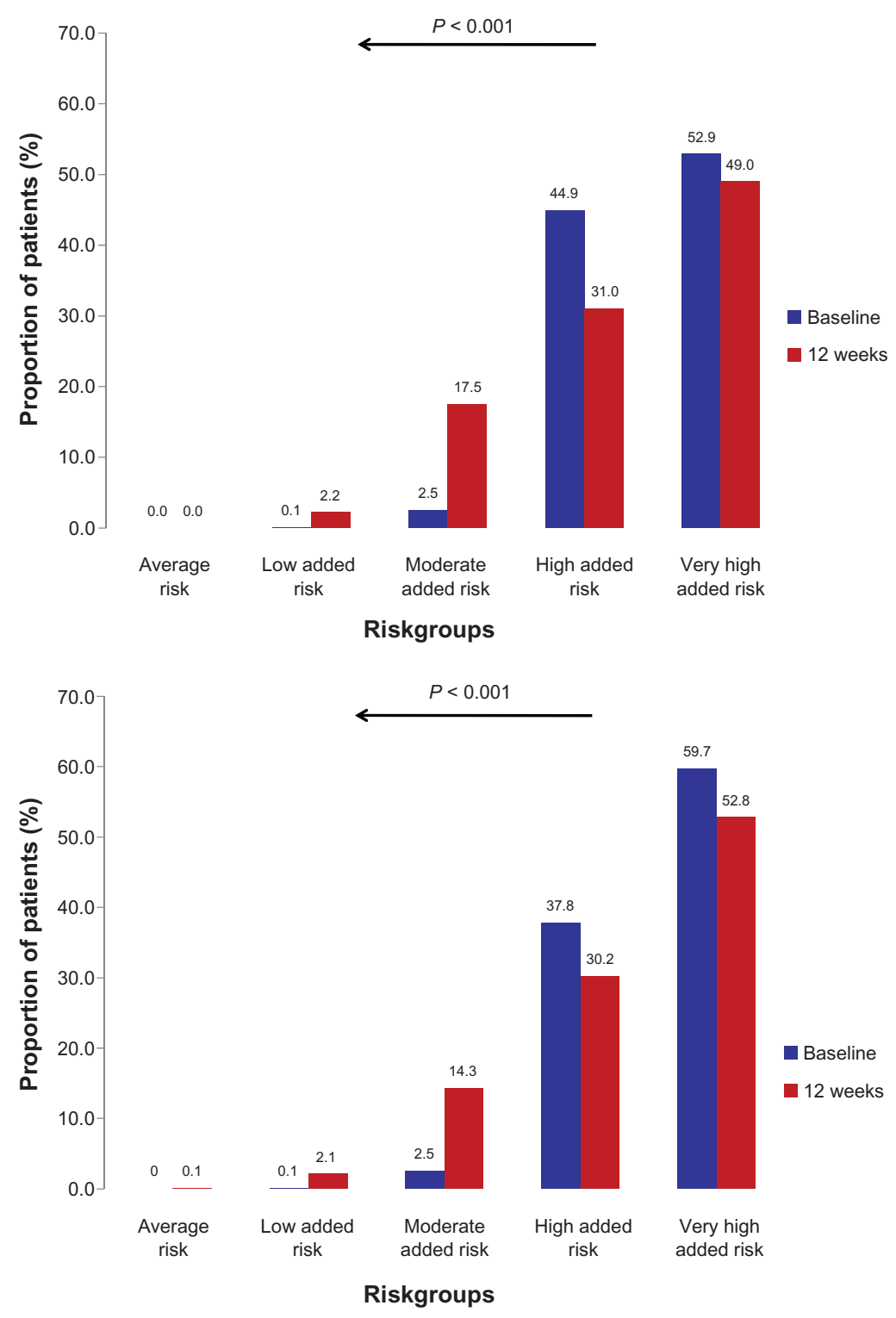

Figure 2 Cardiovascular risk (\%) at baseline and after follow-up according to the European Society of Hypertension/European Society of Cardiology 2007 guidelines. ${ }^{21}$ Upper panel: patients receiving candesartan/hydrochlorothiazide; Lower panel: patients receiving candesartan $32 \mathrm{mg}$. Stratification of cardiovascular risk in five categories. Low, moderate, high, and very high added risk refers to 10 -year risk of a cardiovascular fatal or nonfatal event. 
outlined in the European Society of Hypertension (ESH)/ European Society of Cardiology (ESC) guidelines (Figure 2, panel A and B). ${ }^{21}$ This applied to $44.9 \%$ (high) and $52.9 \%$ (very high) of patients with the fixed-dose combination, and to $37.8 \%$ (high) and $59.7 \%$ (very high) in the high-dose monotherapy group. Risk was substantially reduced at the 12 -week follow-up $(P<0.001$ vs baseline in both groups); substantially fewer patients had high or very high added risk, and more patients had low or moderate added risk. Differences between both treatment groups were negligible.

\section{Blood pressure in patient subgroups}

The blood pressure reduction in subgroups of patients defined by prior or concomitant antihypertensive pharmacotherapy is displayed in Table 3. Differences compared with baseline were significant $(P<0.001)$, with the least effect observed in patients with prior ARB therapy and those with concomitant use of ACE inhibitors. Pronounced effects were observed in patients with prior $\beta$-blocker or diuretic therapy.
Differences between mono- and dual-combination therapy in the respective subgroups were generally in favor of high-dose monotherapy but were significant only for patients for whom a $\beta$-blocker was withdrawn $(P=0.006)$.

Blood pressure reductions were further investigated in subgroups of patients defined by age, gender, and BMI (Figure 3; two panels first row), dyslipidemia, waist circumference, and smoking (Figure 3; two panels second row), and prior cardiovascular event, glomerular filtration rate, and the presence of microalbuminuria (Figure 3; two panels last row). Differences were significant for patients aged $\leq 65$ years, patients with $\mathrm{BMI} \geq 30 \mathrm{~kg} / \mathrm{m}^{2}$, patients with dyslipidemia, and those who smoke $(P<0.05)$.

\section{Metabolic parameters and tolerability}

Twelve weeks after candesartan cilexetil/HCTZ initiation, laboratory values such as glycated hemoglobin, fasting and postprandial glucose, lipids, and renal parameters generally improved, irrespective of whether mono- or combination therapy was employed (Table 4). Differences between treatments

Table 3 Blood pressure reduction versus baseline with respect to prior and concomitant pharmacotherapy for the treatment of hypertension

\begin{tabular}{|c|c|c|c|c|c|c|c|}
\hline & \multicolumn{3}{|c|}{$\begin{array}{l}\text { Candesartan } 16 \mathrm{mg}+ \\
\text { hydrochlorothiazide } 12.5 \mathrm{mg}\end{array}$} & \multicolumn{3}{|c|}{ Candesartan 32 mg } & \multirow{2}{*}{$\begin{array}{l}P \text {-value } \\
\Delta \text { combination vs } \\
\Delta \text { monotherapy }\end{array}$} \\
\hline & $\begin{array}{l}\text { No. of } \\
\text { patients }\end{array}$ & $\begin{array}{l}\text { Blood } \\
\text { pressure } \\
\text { reduction } \\
(\mathrm{mm} \mathrm{Hg})\end{array}$ & $\begin{array}{l}P \text {-value vs } \\
\text { baseline }\end{array}$ & $\begin{array}{l}\text { No. of } \\
\text { patients }\end{array}$ & $\begin{array}{l}\text { Blood } \\
\text { pressure } \\
\text { reduction } \\
(\mathrm{mm} \mathrm{Hg})\end{array}$ & $\begin{array}{l}\text { P-value vs } \\
\text { baseline }\end{array}$ & \\
\hline \multicolumn{8}{|l|}{ Prior therapy } \\
\hline No change of prior therapy & 905 & 28.39 & $<0.001$ & 373 & 29.57 & $<0.001$ & 0.166 \\
\hline Change of prior therapy & 2395 & 28.53 & $<0.001$ & 865 & 29.78 & $<0.001$ & 0.037 \\
\hline \multicolumn{8}{|l|}{ Withdrawn therapy } \\
\hline $\begin{array}{l}\text { Angiotensin-converting } \\
\text { enzyme inhibitors }\end{array}$ & 1377 & 28.66 & $<0.001$ & 494 & 30.21 & $<0.001$ & 0.046 \\
\hline Angiotensin receptor blockers & 391 & 25.71 & $<0.001$ & 190 & 26.20 & $<0.001$ & 0.681 \\
\hline$\beta$-blockers & 327 & 28.52 & $<0.001$ & 130 & 33.06 & $<0.001$ & 0.006 \\
\hline Calcium channel blockers & 342 & 30.33 & $<0.001$ & 122 & 30.34 & $<0.001$ & 0.996 \\
\hline Diuretics & 427 & 30.40 & $<0.001$ & 53 & 32.96 & $<0.001$ & 0.259 \\
\hline \multicolumn{8}{|l|}{ No. of withdrawn drugs } \\
\hline I drug withdrawn & 1933 & 28.22 & $<0.001$ & 745 & 29.29 & $<0.001$ & 0.090 \\
\hline$\geq 2$ drugs withdrawn & 468 & 29.82 & $<0.001$ & 121 & 32.39 & $<0.001$ & 0.161 \\
\hline \multicolumn{8}{|l|}{ Concomitant pharmacotherapy } \\
\hline $\begin{array}{l}\text { Angiotensin-converting } \\
\text { enzyme inhibitors }\end{array}$ & 34 & 27.79 & $<0.001$ & 34 & 29.85 & $<0.001$ & 0.556 \\
\hline Angiotensin receptor blockers & 9 & 30.22 & $<0.001$ & 3 & 47.67 & 0.019 & 0.099 \\
\hline$\beta$-blockers & 230 & 30.71 & $<0.001$ & 95 & 29.07 & $<0.001$ & 0.403 \\
\hline Calcium channel blockers & 204 & 30.39 & $<0.001$ & 95 & 29.47 & $<0.001$ & 0.649 \\
\hline Diuretics & $|3|$ & 29.60 & $<0.001$ & 150 & 30.25 & $<0.001$ & 0.741 \\
\hline \multicolumn{8}{|l|}{ No. of concomittant drugs } \\
\hline No concomitant drugs & 2659 & 28.27 & $<0.001$ & 908 & 29.36 & $<0.001$ & 0.049 \\
\hline I concomittant drug & 1047 & 28.65 & $<0.001$ & 350 & 30.73 & $<0.001$ & 0.020 \\
\hline$\geq 2$ concomittant drugs & 2271 & 28.42 & $<0.001$ & 899 & 29.35 & $<0.001$ & 0.113 \\
\hline
\end{tabular}



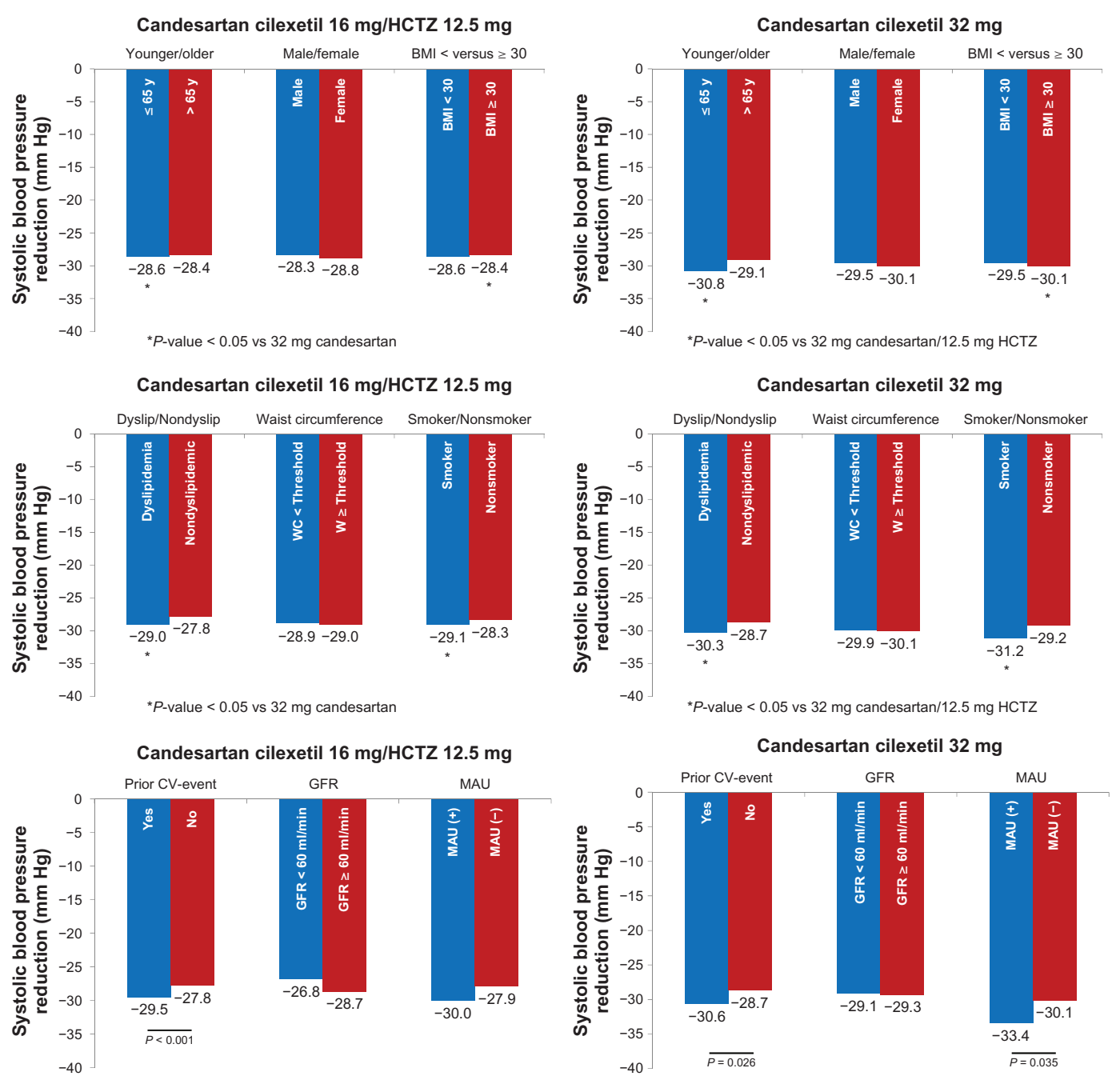

Figure 3 Systolic blood pressure reduction patient characteristic (age, gender, and BMI: two panels first row), concomitant risk factors (hyperlipidemia, waist circumference, smoking: two panels second row), and end-organ damage (prior CV event, GFR, and MAU: two panels last row).

Notes: *Significant differences are indicated ( $P$-value). Other comparisons are not significant.

Abbreviations: BMI, body mass index; CV, cardiovascular; GFR, glomerular filtration rate; HCTZ, hydrochlorothiazide; MAU, microalbuminuria.

were, however, nonsignificant. During the course of the observation, 28 adverse events were reported in patients receiving a fixed-combination treatment $(\mathrm{n}=28 / 3337 ; 0.8 \%)$ and 15 in the monotherapy treatment group $(\mathrm{n}=15 / 1263 ; 1.2 \%)$. One event in each group was considered to be serious. Most adverse events were related to cardiac or vascular disorders. Details are displayed in Table 5 (MedDRA ${ }^{\circledR}$ Primary System Organ Classes, Northrop Grummon Corporation, California, US).

\section{Discussion}

Awareness that the majority of patients require two or more antihypertensive agents to reach their blood pressure goal led to the therapeutic concept to introduce combination treatment early, which usually comprises a thiazide diuretic. ${ }^{21,22}$ On the other hand, clinical study evidence also suggests that sustainable inhibition of the renin-angiotensin-aldosterone system (RAAS) at the tissue level, as provided by high-dose monotherapy with an ARB, might afford improved cardiovascular protection beyond pure blood pressure reduction. ${ }^{19}$ There is, however, no recommendation on this decision to either combine or increase dose, and reports on clinical experience from primary care are sparse. Therefore, we designed a noninterventional study, the key findings of which are as follows. First, the fixeddose combination of candesartan cilexetil $16 \mathrm{mg}$ and HCTZ $12.5 \mathrm{mg}$ and high-dose monotherapy with candesartan $32 \mathrm{mg}$ was almost equally effective at lowering blood pressure in patients at increased cardiovascular risk. Blood pressure reduction was enhanced with higher baseline blood pressure. Differences were small in subgroups defined by patients' characteristics, risk factors, and end-organ disease. Second, the degree of added cardiovascular risk, as outlined by the 
Table 4 Laboratory values at baseline and during follow-up

\begin{tabular}{|c|c|c|c|c|c|c|c|}
\hline & \multicolumn{3}{|c|}{$\begin{array}{l}\text { Candesartan } 16 \mathrm{mg}+ \\
\text { hydrochlorothiazide } 12.5 \mathrm{mg}\end{array}$} & \multicolumn{3}{|c|}{ Candesartan 32 mg } & \multirow{2}{*}{$\begin{array}{l}P \text {-value } \\
\Delta \text { combination vs } \\
\Delta \text { monotherapy }\end{array}$} \\
\hline & Baseline & 12 weeks & $\Delta$ vs baseline & Baseline & 12 weeks & $\Delta$ vs baseline & \\
\hline \multicolumn{8}{|l|}{ Blood glucose } \\
\hline $\begin{array}{l}\text { Fasting blood } \\
\text { glucose }(\mathrm{mg} / \mathrm{dL})\end{array}$ & $108.8 \pm 28.9$ & $103.2 \pm 25.8$ & $5.5 \pm 18.5$ & $110.5 \pm 32.2$ & $106.3 \pm 27.5$ & $4.19 \pm 23.26$ & 0.257 \\
\hline $\begin{array}{l}\text { Postprandial } \\
\text { glucose }(\mathrm{mg} / \mathrm{dL})\end{array}$ & $147.7 \pm 34.9$ & $136.6 \pm 32.1$ & $I I . I \pm 27.1$ & $148.6 \pm 40.3$ & $136.6 \pm 37.3$ & $12.0 \pm 34.9$ & 0.717 \\
\hline \multicolumn{8}{|l|}{ Lipids } \\
\hline Total cholesterol (mg/dL) & $218.2 \pm 34.6$ & $205.0 \pm 34.5$ & $13.3 \pm 29.0$ & $220.4 \pm 43.3$ & $210.9 \pm 86.7$ & $9.4 \pm 86.4$ & 0.351 \\
\hline $\begin{array}{l}\text { High-density lipoprotein } \\
\text { cholesterol (mg/dL) }\end{array}$ & $51.1 \pm 15.2$ & $52.6 \pm 16.1$ & $1.50 \pm 10.0$ & $52.4 \pm 16.6$ & $53.8 \pm 19.5$ & $1.4 \pm 16.8$ & 0.883 \\
\hline $\begin{array}{l}\text { Low-density lipoprotein } \\
\text { cholesterol ( } \mathrm{mg} / \mathrm{dL})\end{array}$ & $131.9 \pm 34.9$ & $121.9 \pm 30.2$ & $9.95 \pm 25.4$ & $135.0 \pm 43.9$ & $122.7 \pm 32.3$ & $12.3 \pm 40.6$ & 0.296 \\
\hline Triglycerides (mg/dL) & $187.0 \pm 92.7$ & $168.7 \pm 71.6$ & $18.3 \pm 65.8$ & $189.1 \pm 96.2$ & $173.4 \pm 112.6$ & $15.7 \pm 109.8$ & 0.650 \\
\hline \multicolumn{8}{|l|}{ Renal parameters } \\
\hline Serum-creatinine $(\mathrm{mg} / \mathrm{dL})$ & $1.55 \pm 7.3$ & $1.04 \pm 1.5$ & $0.5 \pm 7.4$ & $2.3 \pm 10.3$ & $\mathrm{I} . \mathrm{I} \pm 0.7$ & $1.24 \pm 10.3$ & 0.157 \\
\hline $\begin{array}{l}\text { Glomerular filtration } \\
\text { rate }\left(\mathrm{mL} / \mathrm{min} / 1.73 \mathrm{~m}^{2}\right)\end{array}$ & $71.6 \pm 12.2$ & $73.5 \pm 22.7$ & $1.90 \pm 12.17$ & $64.8 \pm 21.4$ & $67.4 \pm 22.4$ & $2.6 \pm 13.9$ & 0.664 \\
\hline Albuminuria (mg/24 h) & $76.5 \pm 213.0$ & $46.7 \pm 87.8$ & $30.7 \pm 172.8$ & $123.6 \pm 253.1$ & $84.2 \pm 205.8$ & $39.03 \pm 133.9$ & 0.666 \\
\hline
\end{tabular}

ESH/ESC guidelines, ${ }^{21,23}$ was substantially reduced in both treatment groups. Third, tolerability was high, with $0.8 \%$ of patients experiencing adverse events in the fixed-combination and $1.2 \%$ in the high-dose monotherapy group. Fourth, physicians chose to use high-dose monotherapy in patients with more advanced disease.

\section{Blood pressure reduction in CHILI Triple $T$ in perspective}

Clinical trials evaluating candesartan monotherapy or candesartan/HCTZ combination therapy consistently show safe and effective blood pressure reduction. ${ }^{7,24-29}$ Furthermore, there is evidence from a study published by Ohma et al that the ARB candesartan is more effective compared with the first-generation ARB losartan. The reduction in blood pressure and the proportion of patients with normalized blood pressure were greater with the candesartan $16 \mathrm{mg}$ and HCT $12.5 \mathrm{mg}$ combination than with the losartan $50 \mathrm{mg}$ and HCT $12.5 \mathrm{mg}$ combination, ${ }^{30}$ supporting the interpretation that not all ARBs are similarly effective. The antihypertensive effect of candesartan and HCT has been shown to be dose related over a wide range of doses, and the effects of the components are fully

Table 5 Number of patients with adverse events or serious adverse events during the survey and adverse events coded by MedDRA ${ }^{\circledR}$ Version II.I (safety population: $n=4600$ )

\begin{tabular}{|c|c|c|c|c|}
\hline & \multicolumn{2}{|c|}{$\begin{array}{l}\text { Candesartan } 16 \mathrm{mg} \text { + hydrochlorothiazide } \\
12.5 \mathrm{mg}(\mathrm{n}=3337)\end{array}$} & \multicolumn{2}{|c|}{ Candesartan $32 \mathrm{mg}(\mathrm{n}=1263)$} \\
\hline & $\mathbf{n}$ & $\%$ & n & $\%$ \\
\hline No adverse events & 3313 & 99.3 & 1245 & 98.6 \\
\hline Any adverse events & 24 & 0.7 & 18 & 1.4 \\
\hline Serious adverse events & 1 & 0.0 & 2 & 0.2 \\
\hline Not serious & 23 & 0.7 & 16 & 0.9 \\
\hline \multicolumn{5}{|l|}{ MedDRA ${ }^{\circledR}$ primary system organ classes } \\
\hline Adverse events & 24 & 100 & 18 & 100 \\
\hline General disorders and administration site conditions & 1 & 4.2 & 1 & 5.6 \\
\hline Skin and subcutaneous tissue disorders & 3 & 12.5 & I & 5.6 \\
\hline Respiratory, thoracic, and mediastinal disorders & 4 & 16.7 & 6 & 33.3 \\
\hline Gastrointestinal disorders & 3 & 12.5 & I & 5.6 \\
\hline Nervous system disorders & 2 & 8.3 & I & 5.6 \\
\hline Vascular disorders & 5 & 20.8 & 1 & 5.6 \\
\hline Cardiac disorders & 4 & 16.7 & 4 & 22.2 \\
\hline Musculoskeletal and connective tissue disorders & I & 4.2 & I & 5.6 \\
\hline Investigations & I & 4.2 & I & 5.6 \\
\hline
\end{tabular}


additive. ${ }^{31}$ The present study comparing high-dose candesartan $32 \mathrm{mg}$ monotherapy with candesartan and HCTZ combination therapy revealed similar effective blood pressure reduction of both treatment regimens (Figure 1) independent of the baseline risk stratification (Figure 2). A higher baseline risk (which corresponds to a higher blood pressure at baseline) consistently resulted in a more pronounced blood pressure reduction of the respective treatment regimen. These results support the use of both treatment regimens for hypertensive patients, spanning the complete risk spectrum of hypertension-induced complications independent of risk at baseline.

\section{High-dose monotherapy versus dual-combination treatment}

Based on the results of the present study, both treatment regimens were similarly effective at reducing blood pressure. Systolic blood pressure reduction was slightly more pronounced in the high-dose monotherapy group, but this difference disappeared when grouping patients according to baseline grade of hypertension (Figure 1).

The rationale for combining an $\mathrm{ARB}$ with $\mathrm{HCTZ}$ is that the mechanism of action is complementary and RAAS blockade augments the blood pressure-lowering efficacy of diuretics while alleviating their adverse effects. Thiazide diuretics lower blood pressure through natriuresis, resulting in volume depletion and reduction of peripheral vascular resistance over time. ${ }^{32,33}$ Combining an $\mathrm{ARB}$ with a diuretic reduces vasoconstriction mediated by angiotensin II, at the same time reducing volume and enhancing the efficacy of both antihypertensive components. Therefore, combination therapy may help patients attain blood pressure control in a timelier manner. To achieve this, ARBs at a standard dose are usually combined with low-dose diuretics. ${ }^{34}$ The rationale to use high-dose ARBs is their proven protective effect for end-organs. Their particular benefit relates to their protective effect on end-organs such as the heart, ${ }^{8-11}$ kidneys, ${ }^{12-16}$ and brain. ${ }^{17,18}$ However, results were usually obtained with high doses of candesartan cilexetil, such as $32 \mathrm{mg}$ or even higher, as applied in the SMART (Supra Maximal Atacand Renal Trial). ${ }^{34}$ An advantage of including a high-dose ARB in antihypertensive treatment is the low rate of adverse events associated with this class compared with other antihypertensive agents. ${ }^{35,36}$ Both ARB and HCTZ combination and ARB monotherapy have been shown to be associated with a low rate of treatment discontinuations. ${ }^{37}$ Taking into account these considerations, a further rational approach would be to make use of the end-organ protective effect using $32 \mathrm{mg}$ of an $\mathrm{ARB}$ and combining this dose with $\mathrm{HCTZ}$ as outlined previously. This has been shown to be effective in clinical trials, and further clinical practice research is ongoing. ${ }^{29}$ We were able to show that younger people aged $\leq 65$ years, patients with dyslipidemia, smokers, patients with a prior cardiovascular event, and patients with microalbuminuria had improved blood pressure reduction in the high-dose candesartan monotherapy group compared with patients without the respective condition. Physicians were also more likely to assign highdose monotherapy to patients with pre-existing (vascular) disease. These findings are in accordance with observations showing that the use of an $\mathrm{ARB}$ reduces both proteinuria and the rate of deterioration of renal function beyond those seen with equivalent blood pressure reduction from conventional antihypertensive agents. ${ }^{12-16}$ In particular, proteinuria has been a marker of kidney disease, and recent research has shown that renal and cardiovascular outcomes seem to correlate with the pretreatment levels of proteinuria and with the reduction of proteinuria with treatment. ${ }^{38-42}$ In the present trial, patients on candesartan experienced higher reductions in microalbuminuria in the candesartan high-dose arm compared with the candesartan and HCTZ combination treatment arm, although this change did not reach statistical significance. However, patients with prior microalbuminuria responded to candesartan with increased blood pressure reduction, which might reflect organ-protective effects of high-dose RAAS blockade.

\section{Classification of cardiovascular risk and impact of candesartan cilexetil treatment}

The ESH/ESC guidelines recommend total cardiovascular risk evaluation in every patient in order to refine pharmacotherapy. The blood pressure threshold at which to commence drug administration, the target blood pressure to be reached by drug treatment, and the decision to use two-drug combinations as an initial treatment step are influenced by this classification. ${ }^{43}$ The 2009 update of this guideline now underlines that the presence of subclinical organ damage results in cardiovascular risk to be in the high range, ie, an absolute risk of at least 20 cardiovascular events in 100 patients within 10 years. ${ }^{44}$ The update further expresses that there is indisputable evidence that major drug classes differ in their ability to protect against overall cardiovascular risk or cause-specific cardiovascular events such as stroke and myocardial infarction. ${ }^{44}$

We were able to demonstrate with this noninterventional study that added cardiovascular risk is substantially lowered with either high-dose mono- or combination therapy including candesartan cilexetil. Although several two-drug combinations are suitable for clinical use, outcome trials point to a favorable role of combining RAAS blocking agents 
with diuretics. ${ }^{45}$ Further, there is a particular role for ARBs, eg, candesartan cilexetil, in patients with diabetes. ${ }^{44}$

\section{Limitations}

The present results have to be considered against the background of potential limitations. The study was not controlled, and therefore the role of a placebo effect or the withdrawal of antihypertensive agents is unknown. Second, in the absence of a randomization procedure, the influence of unknown biases, eg, through patient selection, cannot be ruled out. Thus, we observed more patients with higher risk and more concomitant diseases in the monotherapy group. This selection clearly indicates that physicians preferred monotherapy in the group with higher risk and avoided diuretic impairment. Concomitant diuretic prescription could be due to a higher rate of kidney disease. Third, changes in concomitant medication influencing the metabolic profile (eg, lipid-lowering drugs, oral antidiabetic agents, or insulin) have not been documented in the present study. However, it should be kept in mind that observational studies in primary care, including typical patient groups and reflecting current treatment approaches, are useful for complementing the findings of randomized controlled trials. ${ }^{46}$

\section{Conclusion}

Both the fixed-dose combination of candesartan cilexetil $16 \mathrm{mg}$ and HCTZ $12.5 \mathrm{mg}$ and high-dose monotherapy with candesartan $32 \mathrm{mg}$ are highly effective and safe for lowering blood pressure in patients at increased cardiovascular risk with mild, moderate, or severe hypertension. The choice of either strategy therefore largely depends on the principal aim: blood pressure reduction with pronounced volume restriction or pronounced additional end-organ protection.

\section{Authors' contributions}

Takeda Pharma GmbH designed the study. Peter Bramlage explored the data, requested statistical analyses from the clinical research organization (responsible statistician Dr Frank Romanowski), and wrote the first draft of the manuscript with Gerd Bönner. Bernhard Landers revised the manuscript for important intellectual content. All authors reviewed and approved the final manuscript.

\section{Acknowledgments}

This noninterventional study was conducted by Takeda Pharma GmbH, Aachen, Germany. We would like to thank the participating physicians for their assistance and all patients observed during the study. Special gratitude is offered to the clinical research organization Immedis $\mathrm{GmbH}$ for data processing and conducting the statistical analyses.

\section{Disclosure}

Gerd Bönner and Peter Bramlage have been receiving honoraria for talks/consulting and research support from Takeda Pharma $\mathrm{GmbH}$. Bernhard Landers reports no conflict of interest.

\section{References}

1. Lacourciere Y, Asmar R. A comparison of the efficacy and duration of action of candesartan cilexetil and losartan as assessed by clinic and ambulatory blood pressure after a missed dose, in truly hypertensive patients: a placebo-controlled, forced titration study. Candesartan/Losartan Study Investigators. Am J Hypertens. 1999;12: $1181-1187$.

2. Andersson OK, Neldam S. A comparison of the antihypertensive effects of candesartan cilexetil and losartan in patients with mild to moderate hypertension. J Hum Hypertens. 1997;11 Suppl 2:S63-S64.

3. Farsang C, Kawecka-Jaszcz K, Langan J, et al. Antihypertensive effects and tolerability of candesartan cilexetil alone and in combination with amlodipine. Clin Drug Invest. 2001;21:17-13.

4. Himmelmann A, Keinanen-Kiukaanniemi S, Wester A, et al. The effect duration of candesartan cilexetil once daily, in comparison with enalapril once daily, in patients with mild to moderate hypertension. Blood Press. 2001;10:43-51.

5. Philipp T, Letzel H, Arens HJ. Dose-finding study of candesartan cilexetil plus hydrochlorothiazide in patients with mild to moderate hypertension. J Hum Hypertens. 1997;11 Supp1 2: S67-S68.

6. Koenig W. The Multicentre Study Group. Comparison of the efficacy and tolerability of combination tablets containing candesartan cilexetil and hydrochlorothiazide or losartan and hydrochlorothiazide in patients with moderate to severe hypertension. Results of the CARLOS study. Clin Drug Investig. 2000;19:239-246.

7. Bönner G, Fuchs W. Fixed combination of candesartan with hydrochlorothiazide in patients with severe primary hypertension. Curr Med Res Opin. 2004;20:597-602.

8. Granger CB, McMurray JJ, Yusuf S, et al. Effects of candesartan in patients with chronic heart failure and reduced left-ventricular systolic function intolerant to angiotensin-converting-enzyme inhibitors: the CHARM-Alternative trial. Lancet. 2003;362:772-776.

9. Pfeffer MA, Swedberg K, Granger CB, et al. Effects of candesartan on mortality and morbidity in patients with chronic heart failure: the CHARM-Overall programme. Lancet. 2003;362:759-766.

10. Yusuf S, Pfeffer MA, Swedberg K, et al. Effects of candesartan in patients with chronic heart failure and preserved left-ventricular ejection fraction: the CHARM-Preserved Trial. Lancet. 2003;362: 777-781.

11. McMurray JJ, Ostergren J, Swedberg K, et al. Effects of candesartan in patients with chronic heart failure and reduced left-ventricular systolic function taking angiotensin-convertingenzyme inhibitors: the CHARM-Added trial. Lancet. 2003;362: 767-771.

12. Mogensen CE, Neldam S, Tikkanen I, et al. Randomised controlled trial of dual blockade of renin-angiotensin system in patients with hypertension, microalbuminuria, and non-insulin dependent diabetes: the candesartan and lisinopril microalbuminuria (CALM) study. BMJ. 2000;321:1440-1444.

13. Trenkwalder P, Lehtovirta M, Dahl K. Long-term treatment with candesartan cilexetil does not affect glucose homeostasis or serum lipid profile in mild hypertensives with type II diabetes. $J$ Hum Hypertens. 1997;11 Suppl 2:S81-S83. 
14. Rossing K, Christensen PK, Hansen BV, et al. Optimal dose of candesartan for renoprotection in type 2 diabetic patients with nephropathy: a double-blind randomized cross-over study. Diabetes Care. 2003;26:150-155.

15. Rossing K, Jacobsen P, Pietraszek L, et al. Renoprotective effects of adding angiotensin II receptor blocker to maximal recommended doses of ACE inhibitor in diabetic nephropathy: a randomized double-blind crossover trial. Diabetes Care. 2003;26:2268-2274.

16. Bilous R, Chaturvedi N, Sjolie AK, et al. Effect of candesartan on microalbuminuria and albumin excretion rate in diabetes: three randomized trials. Ann Intern Med. 2009;151:11-20, W3-W4.

17. Lithell H, Hansson L, Skoog I, et al. The Study on Cognition and Prognosis in the Elderly (SCOPE): principal results of a randomized double-blind intervention trial. J Hypertens. 2003;21:875-886.

18. Schrader J, Lüders S, Kulschewski A, et al. The ACCESS study: evaluation of acute candesartan cilexetil therapy in stroke survivors. Stroke. 2003;34:1699-1703.

19. Shargorodsky M, Hass E, Boaz M, et al. High dose treatment with angiotensin II receptor blocker in patients with hypertension: differential effect of tissue protection versus blood pressure lowering. Atherosclerosis. 2008;197:303-310.

20. Baumgart P, Reismann J, Pohlmeyer H, et al. Change from ACE inhibitor, Ca-antagonist or beta-blocker to candesartan cilexetil: better efficacy and tolerance. SWITCH study (German study segment). Dtsch Med Wochenschr. 2001;126:547-550.

21. Mancia G, de Backer G, Dominiczak A, et al. 2007 Guidelines for the Management of Arterial Hypertension: the Task Force for the Management of Arterial Hypertension of the European Society of Hypertension (ESH) and of the European Society of Cardiology (ESC). J Hypertens. 2007;25:1105-1187.

22. Chobanian AV, Bakris GL, Black HR, et al. Seventh Report of the Joint National Committee on Prevention, Detection, Evaluation, and Treatment of High Blood Pressure. Hypertension. 2003;42:1206-1252.

23. Mancia G, Laurent S, Agabiti-Rosei E, et al. Reappraisal of European guidelines on hypertension management: a European Society of Hypertension Task Force document. Blood Press. 2009;18: 308-347.

24. Bramlage P, Schonrock E, Odoj P. Metabolic effects of an AT1receptor blockade combined with $\mathrm{HCTZ}$ in cardiac risk patients: a non interventional study in primary care. BMC Cardiovasc Disord. 2008;8:30.

25. Oparil S, Michelson EL. Long term efficacy, safety, and tolerability of candesartan cilexetil added to hydrochlorothiazide in patients with severe hypertension. Am J Hypertens. 2009;1:20.

26. Edes I. Combination therapy with candesartan cilexetil $32 \mathrm{mg}$ and hydrochlorothiazide $25 \mathrm{mg}$ provides the full additive antihypertensive effect of the components: a randomized, double-blind, parallel-group study in primary care. Clin Drug Investig. 2009;29:293-304.

27. Bramlage P, Schonrock E, Odoj P, et al. Importance of a fixed combination of AT1-receptor blockade and hydrochlorothiazide for blood pressure lowering in cardiac risk patients. A postmarketing surveillance study with Candesartan/HCTZ. MMW Fortschr Med. 2008; 149 Suppl 4:172-181.

28. Uen S, Un I, Fimmers R, et al. Effect of candesartan cilexetil with hydrochlorothiazide on blood pressure and ST-segment depression in patients with arterial hypertension. Dtsch Med Wochenschr. 2007; 132:81-86.

Vascular Health and Risk Management

\section{Publish your work in this journal}

Vascular Health and Risk Management is an international, peerreviewed journal of therapeutics and risk management, focusing on concise rapid reporting of clinical studies on the processes involved in the maintenance of vascular health; the monitoring, prevention and treatment of vascular disease and its sequelae; and the involvement of
29. Bönner G; Multicentre Study Group. Antihypertensive efficacy and tolerability of candesartan-hydrochlorothiazide $32 / 12.5 \mathrm{mg}$ and $32 / 25 \mathrm{mg}$ in patients not optimally controlled with candesartan monotherapy. Blood Press Suppl 2008;2: 22-30.

30. Ohma KP, Milon H, Valnes K. Efficacy and tolerability of a combination tablet of candesartan cilexetil and hydrochlorothiazide in insufficiently controlled primary hypertension: comparison with a combination of losartan and hydrochlorothiazide. Blood Press. 2000;9:214-220.

31. Karlson BW, Zetterstrand S, Olofsson B, et al. A dose-response analysis of candesartan-hydrochlorothiazide combination therapy in patients with hypertension. Blood Press. 2009;18:149-156.

32. Waeber B. Very-low-dose combination: a first-line choice for the treatment of hypertension? J Hypertens Suppl. 2003;21:S3-S10.

33. Waeber B. Combination therapy with ACE inhibitors/angiotensin II receptor antagonists and diuretics in hypertension. Expert Rev Cardiovasc Ther. 2003;1:43-50.

34. Burgess E, Muirhead N, Cotret PP, et al, and the SMART (Supra Maximal Atacand Renal Trial) Investigators. Supramaximal dose of candesartan in proteinuric renal disease. J Am Soc Nephrol. 2009;20: 893-900.

35. Law MR, Wald NJ, Morris JK, et al. Value of low dose combination treatment with blood pressure lowering drugs: analysis of 354 randomised trials. BMJ. 2003;326:1427.

36. Burnier M. Angiotensin II type 1 receptor blockers. Circulation. 2001; 103:904-912.

37. Salerno CM, Demopoulos L, Mukherjee R, et al. Combination angiotensin receptor blocker/hydrochlorothiazide as initial therapy in the treatment of patients with severe hypertension. J Clin Hypertens (Greenwich). 2004;6:614-620.

38. Brenner BM, Cooper ME, de Zeeuw D, et al. Effects of losartan on renal and cardiovascular outcomes in patients with type 2 diabetes and nephropathy. N Engl J Med. 2001;345:861-869.

39. Ruggenenti P, Perna A, Mosconi L, et al. Urinary protein excretion rate is the best independent predictor of ESRF in non-diabetic proteinuric chronic nephropathies. Gruppo Italiano di Studi Epidemiologici in Nefrologia (GISEN). Kidney Int. 1998;53:1209-1216.

40. De Zeeuw D, Remuzzi G, Parving HH, et al. Albuminuria, a therapeutic target for cardiovascular protection in type 2 diabetic patients with nephropathy. Circulation. 2004;110:921-927.

41. De Zeeuw D, Remuzzi G, Parving HH, et al. Proteinuria, a target for renoprotection in patients with type 2 diabetic nephropathy: lessons from RENAAL. Kidney Int. 2004;65:2309-2320.

42. Schmieder RE, Schrader J, Zidek W, et al. Low-grade albuminuria and cardiovascular risk: what is the evidence? Clin Res Cardiol. 2007;96: 247-257.

43. Mancia G, de Backer G, Dominiczak A, et al. 2007 ESH-ESC Practice Guidelines for the Management of Arterial Hypertension: ESH-ESC Task Force on the Management of Arterial Hypertension. J Hypertens. 2007;25:1751-1762.

44. Mancia G, Laurent S, Agabiti-Rosei E, et al. Reappraisal of European guidelines on hypertension management: a European Society of Hypertension Task Force document. J Hypertens. 2009;27:2121-2158.

45. Nash DT. Rationale for combination therapy in hypertension management: focus on angiotensin receptor blockers and thiazide diuretics. South Med J. 2007;100:386-392.

46. Concato J, Shah N, Horwitz RI. Randomized, controlled trials, observational studies, and the hierarchy of research designs. $N$ Engl J Med. 2000;342:1887-1892.

\section{Dovepress}

metabolic disorders, particularly diabetes. This journal is indexed on PubMed Central and MedLine. The manuscript management system is completely online and includes a very quick and fair peer-review system, which is all easy to use. Visit http://www.dovepress.com/ testimonials.php to read real quotes from published authors. 